AGRARIS: Journal of Agribusiness and Rural Development Research

Vol. 7 No. 2 July - December 2021, Pages: 191-206

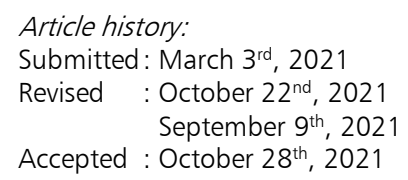

\title{
Challenges and Critical Success Factors for Rural Agrarian Reforms in Limpopo Province, South Africa
}

\author{
DOI: https://doi.org/10.18196/agraris.v7i2.11272
}

\begin{abstract}
The need for rural land agrarian reforms has reached heightened levels in South Africa in recent years. Resultantly, the communal land use effectiveness is questioned due to persistent poor performance and declining agricultural output that fails to address rural poverty and food insecurity. This is one of the major causes of why South Africa's rural economies are generally characterized by stagnant economic growth. This points to deep-rooted and unique challenges that need urgent attention if meaningful support and resilience systems are to be built for rural agrarian land reforms to be realized. The present study investigated challenges and characterized factors that lead to the prosperity of rural agricultural projects in communal land ownership. An exploratory study design was followed, and the data was collected using interviews and focus group discussions from communal farmers and key informants. Data were analyzed thematically with the aid of Atlas. Ti version 8.1.4. "Information challenges" and "water scarcity" describe some of the common challenges faced by rural farmers. Six critical success factors were identified and found to be related. "Effective project management and control" and "improved support from and partnership with local community stakeholders" are success factors that, if targeted first, could address most challenges faced in rural agrarian reforms. The results suggest that partnership with the private sector can help farmers commercialize and move swiftly towards agro-processing. Identified threats and successes must be prioritized in designing and formulating region-specific rural agrarian support programs for communal farmers.
\end{abstract}

Keywords: Agriculture, communal farmers, rural agrarian land reforms, rural development, success factors

\section{INTRODUCTION}

The democratic South African government, after 1994, systematically introduced targeted programs to reduce the vulnerabilities of rural farmers and improve output. These include Reconstruction and Development Program of 1994; and One Household One Hectare of 2015 (Tshuma, 2012; Netshipale, Oosting, Raidimi, Mashiloane, \& de Boer, 2017). Comprehensive Agricultural Support Program introduced in $2004 / 2005$ is in operation 
currently. The program aims to undo the inequalities in farming land access and use as inherited from the apartheid government planning. Specifically, the program assists with, on and off-farm infrastructure support, information \& knowledge management, technical support, advisory services, training, and capacity for rural black farmers. Despite the wide support, fewer success stories are recorded (Quinn, Ziervogel, Taylor, Takama, \& Thomalla, 2011, Vetter, 2013). It suggests a misdiagnosis of the problem and indicates the exisitence of unique challenges that face rural farmers despite the given support. This may also further indicate the adoption of a top-down approach in these support programs. Studies (Dung \& Jenicek, 2008; Ha, Bosch, \& Nguyen, 2015) show that although there are similarities, there are different success rates of rural agrarian reform programs across provinces and regions. It may further indicate use of top-down approach methods in the support programs. Further to that, supported farmers lack resilience and sustainability competence to carry on after the withdrawal of support. Expectedly, rural agricultural output continue to decline as recorded in recent years. This explain the rising levels of household food insecurity in most rural homes. For instance, recently, a report by Statitics South Africa (2019) on quarter to quarter annual growth rates by sector. Agrculture, shows a negative growth $(-7,6 \%)$ and contributed to $-0,2$ of a percentage point to GDP. The fall was a result of a decrease in the production of field and horticultural crops. Rural farmers are reportedly the most affected.

Agriculture is a vital economic sector for most rural communities in sub-Saharan Africa and South Africa. It is the heart of economic development. Its success guarantees food and nutrition security, generates income for farmers, and creates jobs for sustainable rural livelihoods (Sobczyk, 2014; Balkrishna, 2021). In addition, it guards vegetation and animal diversity (Sobczyk, 2014). Moreover, agriculture releases labor, resources, and capital for other businesses (Yuldashev, \& Sultonov, 2020; Balkrishna, 2021). However, success in the sector is not achieved swiftly enough to produce important benefits to farmers and rural livelihoods. This indicates that the current agriculture development support programs have not addressed the sector's sustainability and achieved desired results. It appears that there are unique challenges confronting communal farmers that need context and an area-specific combination of key factors important for the success of rural farmers.

According to Křičková (2015), rural farmers exhibit common triple challenges of limited growth, dependency syndrome, and consummate failure, however varied. This suggests uniqueness in the needs of farmers in different regions and settings. Beckman (2001) contends that misdiagnosis and lack of contextualization of farmers' challenges result in support systems rooted in the top-down and one-size-fits-all approach. Such approaches ignore the fact that societal norms, systems, values, environment, and perceptions shape how the community views, supports, values, and practices agriculture in each region Meijer, Catacutan, Ajayi, Sileshi, \& Nieuwenhuis, 2015). Commercial farmers enjoy economies of scale. Hence, they have access to capital hence can harness the benefits of technological sophistication to adapt to the harsh and fast-changing farming conditions. This does not rue with smallholder and small-scale communal farmers. Thus, any rural agrarian support program that ignores the uniqueness of challenges is poised to fail. This necessitates the need-to-know threats to the 
success of the intended agrarian reforms. It is in this way that success thrusts can be known comprehensively. This helps in devising region-specific strategies and programs that support the prosperity of rural agrarian reforms. This study was conducted in Limpopo province.

Limpopo is a northern province of South Africa that covers $123600 \mathrm{~km} 2$ in area. Its population is over 5.8 million (Statistics South Africa, 2020). Limpopo is largely rural (De Cock et al., 2013) and the province has approximately 10\% of the arable land of South Africa. As the main economic activity, common agricultural crops include grain sorghum, dry beans, soybeans, wheat, and sunflower constituting about 43\%, 22\%, 4\%, 7\%, and 10\%, respectively (Department of Agriculture, Forestry, and Fisheries [DAFF], 2019). Nuts, cotton, and stable foods like maize are also common farmer and market choice crops. The province has more people living in poverty of about 50\% (Statistics South Africa, 2019). Arguably, it is the poorest province in the country. Despite the government's efforts to improve the situation and reduce poverty by supporting rural farmers, the province remains largely poor. The land redistribution schemes such as Settlement Land Acquisition Grant (1995 till 2000), Land Redistribution for Agricultural Development (2001 to 2010) as well as the Proactive Land Acquisition Strategy (2006 to date) (Department of Land Affairs, 1997; 2006) sought after grooming and introducing a new generation of farmers to commercial farming from the previously disadvantaged past. This was part of the national rural agrarian land reform programs in South Africa (MacLeod, McDonald, \& Van Oudtshoorn, 2008). Despite, the introduction of more support programs such as Comprehensive Agricultural Support Program introduced in 2004/5, more than two decades later, relatively few farmers have risen to become successful commercial entrepreneurs (Mafukata, 2015; Mwadzingeni, Mugandani, $\&$ Mafongoya, 2020). This indicates multiple challenges that are unique to the province and hinder the successful transition and rural agrarian reforms.

It is why, currently the provincial government initiatives seek to establish Agri-parks, agriculture co-operatives, promote development of agro-processing industry, and support young farmers as a strategy to achieve intended rural agrarian reforms. The provincial government is committed to supporting agriculture as a tool for sustainable rural development. Annually, over 1000 farmers benefit from sector trainings to improve farmers' skills and production capabilities (DAFF, 2019). With this support and commitment at the local level, rural agriculture projects still fail to yield desired outcomes and reduce poverty (Mpandeli \& Maponya, 2014). It is for this reason why this study was commissioned to identify and isolate issues that hinder the success of rural agrarian reforms in the province targeted at rural agricultural projects. The methods and techniques used to conduct the study are described below.

\section{RESEARCH METHOD}

\section{Study Design and Area Selection Rationale}

A cross-sectional exploratory study design was used to obtain the lived practical contextual experiences for the threats and determinants of success among the rural 
agricultural projects. Ethical clearance was issued by the University of Venda Social Research Ethics Committee (Ethics Certificate Number: SARDF/18/IRD/06/2111). Permission to conduct the study was further sought from three local municipalities located in Vhembe (Thulamela \& Collins Chabane local minimality) and Mopani (Greater-Giyani local municipality) district in Limpopo province, South Africa (Figure 1).

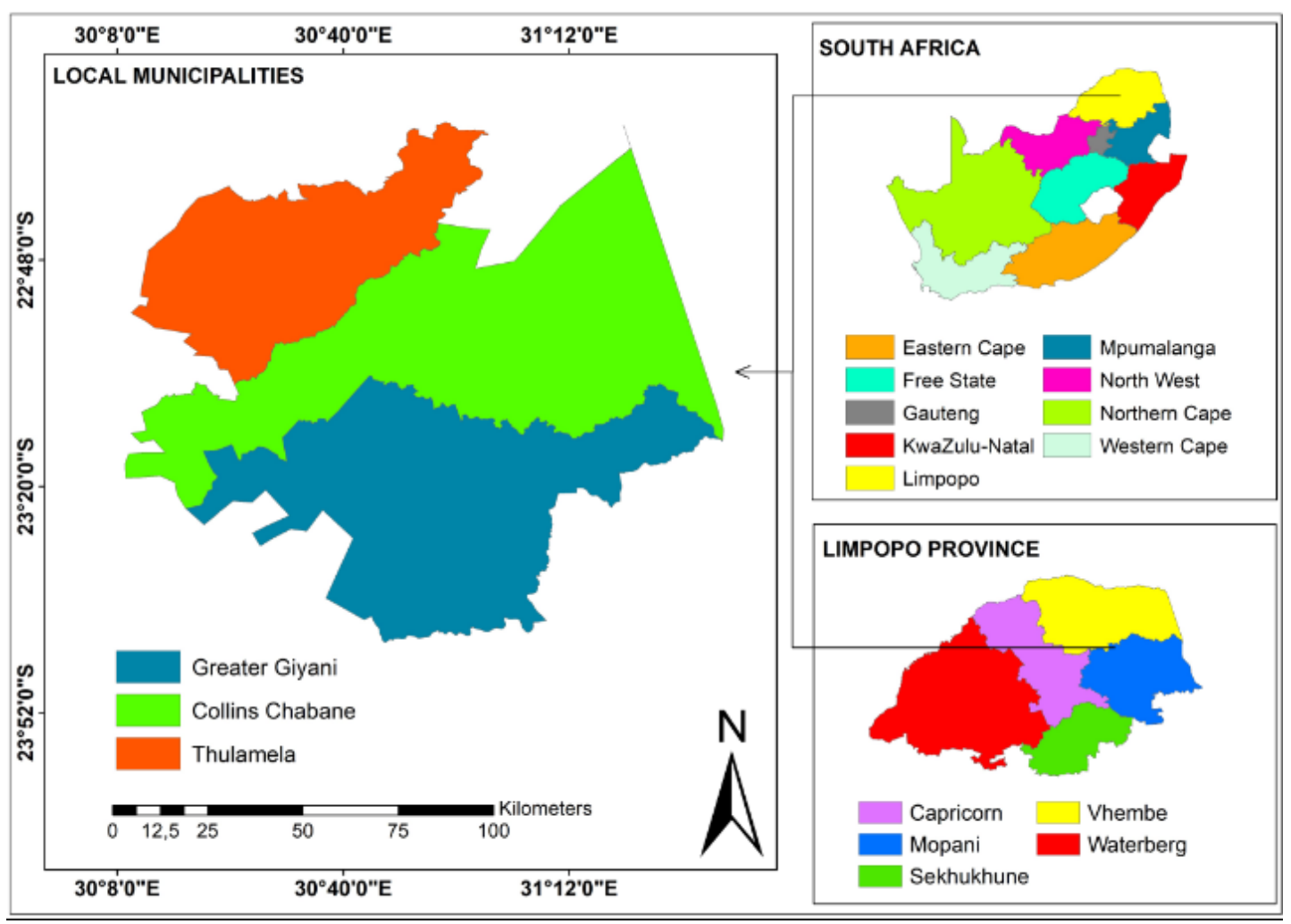

FIGURE 1. STUDY AREA IN MOPANI AND VHEMBE DISTRICT OF LIMPOPO PROVINCE, SOUTH AFRICA

\section{Study population and data collection}

One hundred and three (103) farmers and key informants participated in the study. These comprised of purposively selected communal farmers, operating in three local municipalities. Furthermore, municipal local economic development practitioners specializing in agriculture, traditional leaders, and non-governmental organizations that work closely with farmers in studied areas were selected as key informants and to triangulate the findings. Data were collected through focus group discussions and interviews using semistructured questions with farmers, and key informants, respectively. Two (2) research assistants helped facilitate the data collection process and discussions in local languages (Venda and Xitsonga) to ensure that farmers understood issues better. Detailed notes of interviews and audio records were used to enhance the accuracy of responses. Rural agriculture projects in each municipality were purposively approached. The purpose of the study was presented to the owner, manager, or committee chairperson in the case of a cooperative. On agreement, agricultural projects were included. One project, in Collins Chabane, was included initially and later excluded due to its closure after the preliminary meetings were done. 


\section{Analysis procedure}

Transcribed explorative data was cleaned and captured into Microsoft excel. Thereafter, it was imported into the Atlas Ti network version 8.1 to aid the thematic content analysis. In a series of coding, de-coding, and re-coding, major themes describing challenges and pertinent success factors for agricultural projects were identified. Visual network diagrams showing relationships of identified factors with associated descriptive statements were used for the analysis and understanding of causation.

\section{RESULTS AND DISCUSSION}

\section{Demographic Composition}

Table 1 illustrates demographic profile of 103 participants who took part in the study. More than half of the respondents were female 55 (53.4\%) and over three quarters were above the age of 40 . Thus, there is low participation of youth in rural agricultural projects. Among them, most of the participants had matriculated 63 (61.2\%).

\begin{tabular}{lcc}
\multicolumn{4}{l}{ TABLE 1. PARTICIPANT'S DEMOGRAPHIC PROFILE OF THE STUDY ( $\mathrm{N}=103)$} \\
\hline CATEGORY & Frequency & Percentage (\%) \\
\hline Gender & & \\
Female & 55 & 53.4 \\
Male & 48 & 46.6 \\
Age & & \\
Under 30 years & 8 & 7.8 \\
31 - 40 years & 24 & 23.3 \\
41 - 50 years & 34 & 33.0 \\
$51-60$ years & 27 & 26.2 \\
Over 61 years & 9 & 8.7 \\
Level of Education & & \\
Up to Secondary Education & 39 & 37.9 \\
Matric & 36 & 35.0 \\
Tertiary & 27 & 26.2 \\
Respondent type & & \\
Farmers & 69 & 67.0 \\
Traditional leaders and council members & 27 & 26.2 \\
Government institutions & 4 & 3.9 \\
Non-governmental organization & 3 & 2.9 \\
\hline
\end{tabular}

\section{Characteristics of agricultural projects}

All participating farmers were horticultural producers in the studied agricultural projects. These included cooperatives and individually owned farms under the communal land ownership system. Common crops produced included maize, sweet potatoes, cabbage, tomatoes, Chinese cabbage, and pepper. Nearly, 30\% the of studied farms, were involved in mixed farming. Mainly, poultry. More so, approximately $23 \%$ of the farms cultivated specialized crops. For example, apart from vegetables, a project in Vhembe district focused on herbs and specialized in sweet potato. Similarly, another farm in Greater-Giyani region, 
Mopani district specialized herb production called Lippia javannica [Musudzungwane]. The herb produces oils that are commonly used for mosquito repellents as well as perfumes. The average size of farms was 5.81 ha. Smallest farm was of 3 ha while the largest had 12 ha.

\section{Threats to the success of agricultural projects}

Themes describing major challenges for agricultural projects were categorized as illustrated in Table 2. Results revealed that limited and lack of access to relevant farming information timely was part of the reasons why rural agricultural projects fail. Although extension and municipal officers, said information was given regularly. Farmers were of the view that the information was generic and did not address their immediate unique farm to farm challenges (FGD 5, 6, 7, 9 [Greater-Giyani]; FDG 13 [Thulamela]; FDG 17 [Collins Chabane]). Farmers further explained that information given, lacked matter specificity and context-relevance. Additionally, it did not consider real-time seasonal weather variations and was not regular enough to meet farmer information needs.

TABLE 2. THREATS TO THE SUCCESS OF RURAL AGRICULTURAL PROJECTS IN LIMPOPO, SOUTH AFRICA

\begin{tabular}{|c|c|c|}
\hline Threats to Success & Cause Description & Effect on Success \\
\hline $\begin{array}{l}\text { Limited Support from Local } \\
\text { Stakeholders }\end{array}$ & $\begin{array}{l}\text { - No real value is placed on agriculture \& lack } \\
\text { of interest } \\
\text { - Limited resources } \\
\text { - Role ambiguity and lack of accountability } \\
\text { - No understanding of work done } \\
\text { - Stakeholder's failure to see their role in } \\
\text { agriculture }\end{array}$ & $\begin{array}{l}\text { - Vulnerability to the internal and external } \\
\text { environment } \\
\text { - Limited ability to mobilize resources } \\
\text { - Unbalanced representation of farmer's } \\
\text { interests } \\
\text { - Unfavorable and inappropriate support } \\
\text { policies } \\
\text { - Lack of motivation }\end{array}$ \\
\hline Unstable and Inaccessible Market & $\begin{array}{l}\text { - Inconsistent quality of farm produce } \\
\text { - Far markets } \\
\text { - Reliance on free independent traders \& } \\
\text { buyers } \\
\text { - Inability to penetrate the market }\end{array}$ & $\begin{array}{l}\text { - Low prices \& vulnerability to clearance } \\
\text { pricing } \\
\text { - Financial losses } \\
\text { - Loss of stock }\end{array}$ \\
\hline $\begin{array}{l}\text { Financial Constraints and } \\
\text { Management }\end{array}$ & $\begin{array}{l}\text { - Scarce information on funding opportunities } \\
\text { - No collateral } \\
\text { - Little or no funding proposal writing skills } \\
\text { - Too much paperwork }\end{array}$ & $\begin{array}{l}\text { - Inability to access grants } \\
\text { - Failure to access credit } \\
\text { - No capital and reduced production } \\
\text { - Failure to access developmental funds }\end{array}$ \\
\hline $\begin{array}{l}\text { Lack of Technical Know-How and } \\
\text { Skills }\end{array}$ & $\begin{array}{l}\text { - Low level of education } \\
\text { - Limited training opportunities } \\
\text { - Failure to adopt and operate new farming } \\
\text { technology }\end{array}$ & $\begin{array}{l}\text { - Failure to manage and run farm activities } \\
\text { - Failure to embrace new technologies } \\
\text { - Outdated use and application of farming } \\
\text { techniques } \\
\text { - Low output }\end{array}$ \\
\hline $\begin{array}{l}\text { Unusable and Unavailability } \\
\text { Information }\end{array}$ & $\begin{array}{l}\text { - Generic information } \\
\text { - No prompt information services and sources }\end{array}$ & $\begin{array}{l}\text { - An indifferent effect on the success } \\
\text { - Loss of stock }\end{array}$ \\
\hline Water challenges & $\begin{array}{l}\text { - Climate Change } \\
\text { - Low rainfall } \\
\text { - No money for drilling boreholes }\end{array}$ & - Loss of Crops \\
\hline
\end{tabular}

It was also brought to the fore that, farmers failed to reconcile the information given, due to challenges with comprehension and language-related barriers. This included online 
information sources. Limited contact with several farming experts that support farmers, also limited access to information services for farmers. In this vein, an LED officer added that there is indeed lack of "prompt information and knowledge sharing between players" and "distant located technical services" on crop and animal production threatened farmers' success.

To indicate the severity of this challenge, a project member stated that, "It takes time for us to know some of the diseases or pests that infest our plants. After reporting our problems to the extension officers, they take time to visit and diagnose the problem. We need assistance because in most cases our plants die before we get help". (Interview B16: Collins Chabane Municipal Area). In support of this, an NGO representative, said, “... sometimes all their plants get infected or attacked while waiting. In my observation, ... they have learned to uproot all the plants suspicious of diseases and infections" (Key informant Interview 22, Thulamela Municipal Area). Limited know-how coupled with, the absence of prompt information sources or services said they lose crops to disease infestation, the quality of the produce is also compromised and ultimately, they experience decreased farm output (Two and three FGDs in Thulamela and Collins Chabane local municipality, respectively). As coping strategy, indigenous knowledge systems such as smearing "ashes" on tops of crops were used. Also, farmers uprooted all infected crops to prevent the spread of the disease or pests' attack.

Climate and capital inadequacy induced water challenges also hindered farmers' success. Climate variabilities such as "fluctuating seasonal rainfall" as well as "temperature" emerged as of major concern to most farmers. Additionally, the problem of water access was aggravated by lack of capital. For instance, farmers were unable drill boreholes or erect proper functional irrigation systems and set up green houses. In their words, during a group discussion, one farmer narrated the extent of this challenge. "We need an irrigation system to have a meaningful harvest and currently, we cannot afford it. The one which was donated to us now requires maintenance and unfortunately, we are struggling to service it" (FGD 17: Greater-Giyani Municipal Area). A local economic development municipal officer in Thulamela municipal area echoed these sentiments stating that most farmers cannot afford water access infrastructure on their own and most depend on donations by NGOs, supermarkets and or on grants from the Department of Agriculture (Interview 25: Key informant).

Capital challenges directly affect the ability of farmers to purchase farming implements, inputs, and erect infrastructure. Lack of financial management skills further impeded the ability of farmers to raise funds on their own. Although the local government provided grant or proposal writing assistance, not all farmers got assisted due to limited funding targets. Thus, most farmers miss out on other funding instruments and grants. Permission to Occupy (PTO) land ownership or tenure system, also make it hard for rural communal farmers to access credit as stated by an LED municipal official in Thulamela and NGO representative located in the Greater-Giyani area. Under this system, farmers are only given the permission to occupy the land for farming with no title deeds. As such, land cannot be used as collateral with most financial institutions. A project leader explained that, although they had access to grants, "most of these grants are not sufficient to buy some of the key equipment such as tractors and other inputs to 
increase our output" (Interview 12: Thulamela municipal area). Financial challenges were also linked to another challenge of an inadequate number of farmworkers and skills challenges. For example, a project manager in the Greater-Giyani region said, "To produce enough in the farm, we need more workers however due to limited funds we now rely on temporary workers whom we pay from the little profit we make" (Interview 8: Greater-Giyani Municipal area).

Limited knowledge in farming and accompanying skills also threatens the success of rural farmers. Amid climate variabilities in addition to the use of new breed varieties as a coping strategy, farmers revealed that they are not equipped with the right knowledge to manage and adapt to the new realities. "It will help us to understand the requirements for managing and taking care of these new breeds especially the ones, we get from the shops nowadays" a project (FGD 5: Greater-Giyani municipal area). Two FDGs in Thulamela and two Collins Chabane municipal areas also attested to this. Although farmers said they sometimes attended training courses, it was not enough. Only a "handful of workers or members" could attend and such opportunities were scarce (Interview $8 \& 16$ in Greater-Giyani Collins and Chabane Municipal area, respectively). As a coping strategy, farmers utilized online information services. However, lower levels of education and literacy, deterred comprehension of issues as most online information resources were in English. This affected how farmers adopted and adapted to new technologies and their ability to manage farm activities.

Inadequate support from local stakeholders such as extension services, NGOs, and the private sector was also noted as a challenge inhibiting the success of projects. Lack of interest, not seeing the value in the sector, limited resources, and poor working relations described the reasons for the limited participation of local stakeholders. These sentiments were true in all the municipal areas/regions studied (1 FGD in Greater-Giyani, 3 in Collins Chabane, and 2 in Thulamela). An interview with an NGO official, in Collins Chabane municipal area, revealed that community, leaders, and local institutions were less involved in support of agriculture in the locality. Results suggest that because of poor support, projects found it difficult to access the market, information, and mobilize resources for sustained growth. This could also explain why two NGO representatives, in Thulamela and Greater-Giyani local municipal area, said communal farmers were generally discouraged.

Market access was another challenge for farmers. Two project leaders, a key informant, and four FDGs in Collin Chabane and Thulamela municipalities attested to this. Unreliable crops and animal quality; distant markets; dependence on free independent market agents and consumers; and not being able to breach market entry barriers are factors that make it a nightmare for farmers to access the market. For instance, reliance on independent buyers or traders and the existence of distant markets reportedly forces farmers to sell their produce at clearance prices in most cases only to break-even. In some instances, crops particularly tomatoes, spinach, and cabbage lose freshness and or rot before reaching the market.

\section{Determinants of success for rural agricultural projects}

Respondents' narratives on issues that may lead to success were analyzed to develop themes and sub-themes on critical success factors for rural agricultural projects. Furthermore, 
success factors developed were juxtaposed and linked with how they directly respond to major challenges facing agricultural projects (Figure 2). Involved, proactive, and active stakeholder participation; open and accessible market; and access to the skilled workforce, and continuous training and learning; are examples of factors that need to be natured for rural agricultural projects to succeed.

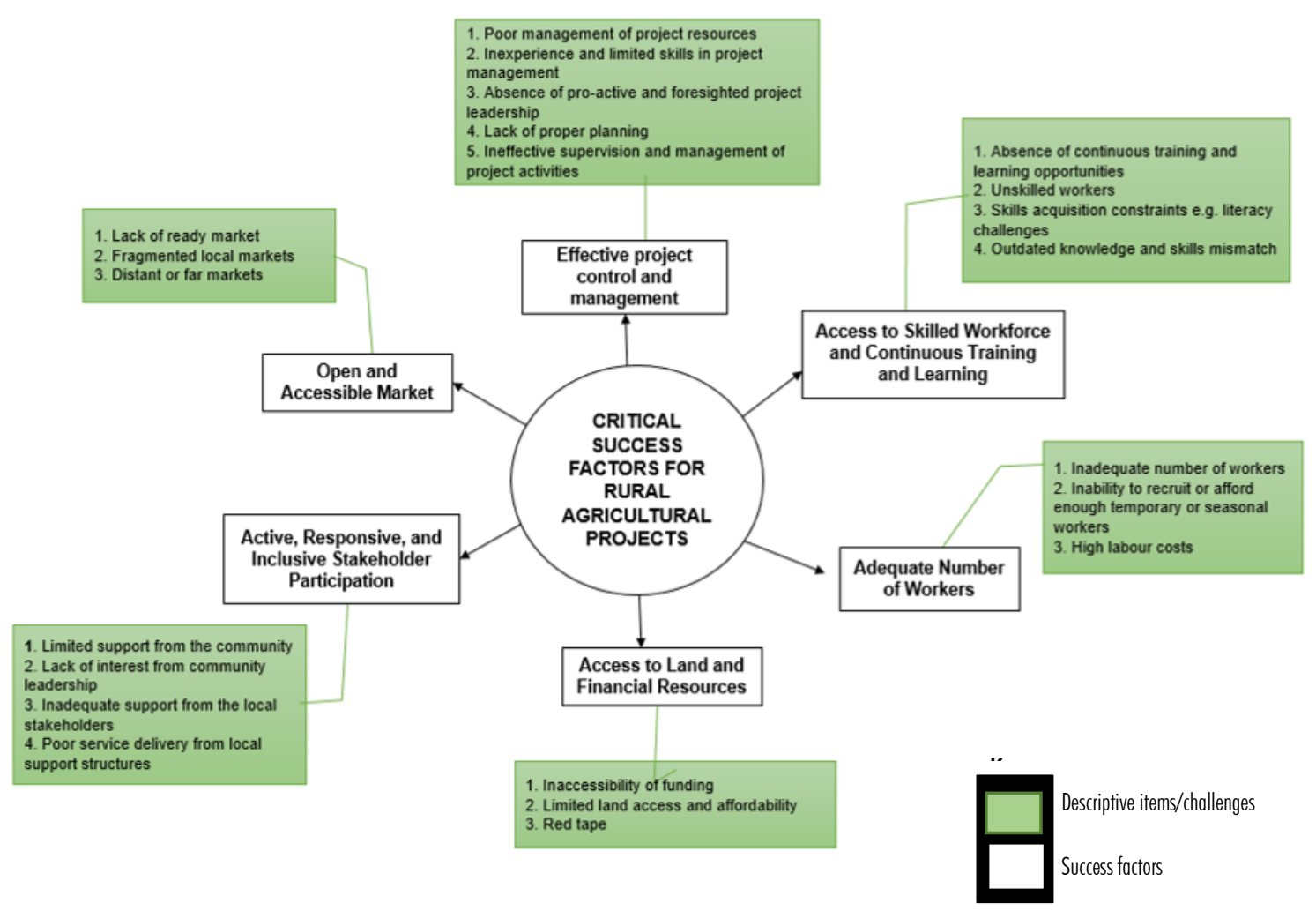

\section{FIGURE 2. CRITICAL SUCCESS FACTORS AND DESCRIPTIVE ITEMS ON CHALLENGES ADDRESSED FACING RURAL AGRICULTURAL PROJECTS IN LIMPOPO PROVINCE, SOUTH AFRICA}

The analysis revealed that improved participation, inclusion, and support of local stakeholders could improve the chances of success for projects. Farmers in all the three municipal areas said, "poor service delivery" and detachment or lack of interest in agriculture by stakeholders such as traditional leaders, extension services, community, and private sector explained partly their lack of progress. It emerged that improved participation has the potential to improve access to finance, market, and information for farmers in the region. For instance, a project manager echoed these sentiments and said, "there is little involvement from extension officers and other players to partner with us in our farming activities" (Interview 8: GreaterGiyani Municipality). Moreover, farmers indicated that partnership with the private sector and NGOs could be useful in supplementing government support services which are currently strained.

Land access was another factor key to the success of rural farmers. It was revealed that land access issues encompassed fertility, ownership, adequacy, and arability. Land inadequacy, for instance, was caused by high prices, and unwillingness as well as lack of agrarian planning 
by tribal authorities as land administrators. In terms of ownership, land owned by farmers belonged to the tribal authority and in most cases, it could not be used as collateral to obtain adequate funding to expand the farming enterprise. This result shows that land access is a key success factor that also strongly influences access to funding for farmers. A farmer said, "poor access to finance, the heartbeat of farming for projects, limited their ability to adapt their farming practices" (FGD 16: Collins Chabane municipal area). For example, a project manager in Thulamela municipality stated that funding challenges, were the reason they could not drill a borehole; erect an irrigation system to deal with water challenges and train their members and workers for improved production.

The ability to effectively manage and control farm activities is another factor that determines success for agricultural projects. Inability to monitor, source funds, plan, organize, and prepare for unforeseeable setbacks explained the failures of most projects in all the municipalities (FGD 4, 16, 17, and 21). A farmer in Collins Chabane municipality was of the view that if farm managers and supervisors took full charge, presented a clear vision, and motivated members/workers, the goals of the project will be adequately met. The analysis revealed that effective management, could improve chances of success by improving access to information, finance, training, and strengthening of stakeholder relationships. Results suggest that effective farm management is the most important factor for running successful rural agricultural projects.

Adequate numbers of members/workers and access to a skilled workforce together with training opportunities were identified as key success factors for agricultural projects. The challenges of failure to manage and monitor farming activities were linked to limited knowhow and basic skills for a successful farming enterprise. A farm manager indicated that due to lack of skills and low level of education, production was slowed down as few skilled individuals or managers are required to do extra monitoring of farmworkers or members (Interview 18: Thulamela municipal area). The municipal officer in Thulamela, an NGO representative, and farmers in all three local municipalities, stressed the necessity and importance of continuous skills training and capacitation. The respondents emphasized the need for farmer to adapt to the changing nature of farming if agricultural projects are to achieve sustained success and growth.

\section{Discussion of Results}

Results revealed that active project management and control; having skilled farm workers, access to continuous training, access to more farming land area, as well as supportive and involved local stakeholders are key factors that if managed and manipulated, intended rural agrarian reforms could be swiftly achieved in Vhembe and Mopane district of South Africa.

Literature (Mukwevho \& Anim, 2014; Sjauw-Koen-Fa et al., 2016; Yusoff, Man, \& Nawi, 2016), supports that inability to penetrate the market is major problem among rural farmers however, it is manifested differently. In this study, market access challenges related to transport, inadequate marketing skills, and limited access market information. These findings 
are similar those by Khapayi \& Celliers (2016). In this light, findings point to the fact that capacitating farmers in skills like marketing, and developing market access strategies for rural farmers could potentially improve prospects of farmers' success. Simalteniously, this could address the multi-dimensional effect of farmers' challenges.

Effective project management and control are among the important factors needed for rural agriculture projects to succeed. Like the findings of this study, the European Network for Rural Development (ENRD) (2015) notes ability to plan effectively and control the farm programs determine the successful implementation of rural development projects. Similarly, continuous monitoring of financial and project operations is imperative for projects to survive (Vukelić \& Rodic, 2014; Yusoff et al., 2016). The authors argue that this factor differentiates between a successful and a failed farm. Vukelić \& Rodic (2014) emphases the importance of record keeping as an effective tool for decisions making which was not common among farmers. In this way, farmers note problems and plan accordingly. Based on this result, rural agrarian support programs must prioritize project management and leadership skills transfer as a sustainable strategy to achieve success for farmers.

The empirical study demonstrated that access to workers with farming knowledge, continuous training as well as learning is an important element to the success of farming operations. Yusoff, Man, \& Nawi (2016) found that technical skills played a central role to the success of small ruminant farmers in Malaysia. Results further revealed that both workers and farm managers must not only have appropriate farming knowledge, but there must adopts a learning culture to adapt rapidly to changing agriculture environment. Similarly, literature shows that both workers and managers must be aware and learn new and emerging farming techniques and methods (Collier \& Dercon, 2014; Salami et al., 2017). Given the climate variabilities currently experienced and advances in farming technology, continuous training and learning is an imperative for quick adaptation. Results of the study support that access to the skilled workforce and continuous training and learning is a critical factor important for rural agrarian reforms to succeed.

Linked to the need for skills, farmers said fewer workers hindered their operations and expansion goals. Capital challenges was the main limiting factor in accessing adequate number of workers. This is a persistent challenge in most rural farmers. For example, Etim \& Okon (2013), found simialr results. The author pointed out capital challenges were multifacated. Authors revelaed thet this challenge did not only liimit accss to ideal farm workers but farmers could not access the alternative benefits from advanced technology for their operations. Also, Nuthall (2012) as well as Akintayo \& Lawal (2016) in Nigeria pointed out that overdependence on manual labour, makes adequate number of workers an important element of success for for rural farming. This could be the reason why farmers emphasises on more workers compared to commercial or well-off farmers that rely on technology to till and harvest for example. Thus, adequate number of workers for rural farmers is a critical factor for success.

Findings suggest that active involvement and participation of local stakeholders is critical in building resilience and facilitating networking with various local, regional, and international partners to support agricultural projects. These findings are like those reported 
in literature by Vermeulen et al. (2012) and Fan, Geddes, \& Flory (2013). Results further suggested that partnership with the private sector would complement government scarce extension services. Equally, participants said the partnership with the private sector offered more opportunities in agro-processing compared to the government services. Thus, an intimate relationship amongst farmers and local development support players such as the private sector is vital to realize success among the projects. Correspondingly in this study, collaboration with stakeholders like farmers' families; local community, and organization; advisory/extension services; non-governmental organizations; and local governance structures are regarded as key to the success of rural farming (Vermeulen et al., 2012; Raleting \& Obi, 2015). These results, show that the success of rural agrarian reforms lie on stakeholder participation and involvement to build a solid network of local support to farmers.

Access to land also emerged as an important factor that determines success for rural farmers. Land access is major challenge to farmers global. However, in this study fewer farmers complained by physical access to land but rather were concerned by the technical access. Absence of title deeds prevented farmers from using land as a guarantor for credit access with financial institutions (Garnevska et al., 2011; Sutherland \& Burton, 2011; White, 2012). These finding corroborates the claim globally and South Africa rural farmers' fail due capital shortages (Gillah et al., 2012; Heyi \& Mberengwa, 2012; Kepe, \& Tessaro, 2014). Thus, rural agrarian reforms program cannot achieve sustainable outcomes without addressing the land ownership question for rural farmers. Any program that does not address this challenge is poised to fail from the onset. This could explain why most rural agricultural projects succeed only during the period of support and fail when the support is withdrawn.

\section{CONCLUSION}

The study investigated challenges and determined important factors required to achieve success in rural agrarian reforms among agricultural projects. Results show that lack of access to information, poor farm management, and low level of support for farmers were some of the main problems hindering success of the intended reforms. The analysis shows that through improving management and leadership, farm workers' skills, availing opportunities for training and learning; and adapting technical access to land the agrarian reforms could be successfully realized. Active support and participation of different stakeholders emerged as the missing critical factor for the success of rural agrarian reforms among rural projects. For instance, farmers stated that apart from inadequate and unreliable government services such as extension services, NGOs and the private sector should get involved and partner with farmers in supporting rural agrarian reforms. This was also said to be the route towards successful commercialization and achieving agro-processing among farmers. Effective project management and support for farmers appeared to be the most important as evidenced linkage to most factors and the ability to address multiple challenges facing projects. Success factors revealed in the study are crucial for formulating apposite and applicable intervention measures to challenges facing rural farmers. Identified challenges and success factors offer a distinct 
multi-dimensional tool that can be applied to improve the likelihood of success to farmers. Given these findings, it is recommended that in designing support programs for farmers, skills development programs should focus on farm management skills and seek to foster partnerships with various local stakeholders to build sustained resilience for projects. Moreover, the study recommends involvement and development of a farmer support model that brings in the private sector to improve the marketing of farmer's produce through engaging in agro-processing activities.

Acknowledgment: National Research Foundation, South Africa: Grant ID Number: 112388

\section{REFERENCES}

Akintayo, O. I., \& Lawal, B. O. (2016). Effect of Land Fragmentation on Technical Efficiency Among Farmers in Southwest Nigeria. International Journal of Science Nature, 7(3), 2016.

Balkrishna, A. (Ed.). (2021). Sustainable Agriculture for Food Security: A Global Perspective (1st ed.). Apple Academic Press. https://doi.org/10.1201/9781003242543

Beckman, M. (2001). Extension, poverty, and vulnerability in Vietnam. In workshop Extension and Rural Development: A Convergence of Views on International Approaches (pp. 12-15).

Collier, P., \& Dercon, S. (2014). African agriculture in 50 years: smallholders in a rapidly changing world?. World Development, 63, 92-101. https://doi.org/10.1016/j.worlddev.2013.10.001

De Cock, N., D'Haese, M., Vink, N., van Rooyen, C. J., Staelens, L., Schonfeldt, H. C., \& D'Haese, L. (2013). Food security in rural areas of Limpopo province, South Africa. Food Secucirty, 5, 269- 282. https://doi.org/10.1007/s12571-013-0247-y

Department of Agriculture, Forestry, and Fisheries. (2019). Trends in the Agriculture Sector 2019. Pretoria, South Africa.

Department of Land Affairs (1997). White Paper on South African Land Policy. Retrivied from: http://ww2.ruraldevelopment.gov.za/DLA-

Internet//content/document_library/documents/White_paper/WhitePaperLandRef orm.pdf. [Accessed November $8^{\text {th }}, 2021$ )

Department of Land Affairs. (2006). Implementation Plan for the Proactive Land Acquisition Strategy. DLA, Peritoria. Retrivied from: https://www.gov.za/sites/default/files/gcis_document/201409/impllandacquisition0. pdf. [Accessed July, 29 ${ }^{\text {th }}, 2021$ ].

Dung, L. V., \& Jenicek, V. (2008). Challenges with Vietnamese agricultural products joining WTO. Agricultura Tropica et subtropical, 41(2), 80-83.

Etim, N. A., \& Okon, S. (2013). Sources of technical efficiency among subsistence maize farmers in Uyo, Nigeria. Discourse Journal of Agriculture and Food Sciences, 1(4), 48-53.

European Network for Rural Development (2015). Getting rurl development programmes going. European Union Rural Review. No 20. 
Fan, D., Geddes, D., \& Flory, F. (2013). The Toyota Recall Crisis: Media Impact on Toyota's Corporate Brand Reputation. Corporate Reputation Review, 16(2), 99-117. https://doi.org/10.1057/crr.2013.6

Garnevska, E., Liu, G., \& Shadbolt, N. M. (2011). Factors for successful development of farmer cooperatives in Northwest China. International Food and Agribusiness Management Review, 14(1030-2016-82904), 69-84.

Gillah, K., Kifaro, G. C., \& Madsen, J. (2012). Urban and peri-urban dairy farming in East Africa: A review on production levels, constraints and opportunities. Livestock Research for Rural Development, 24(11), 198.

Ha, T. M., Bosch, O. J. H., \& Nguyen, N. C. (2015). Necessary and Sufficient Conditions for Agribusiness Success of Small-scale Farming Systems in Northern Vietnam. Business and Management Studies, 1(2), 36. https://doi.org/10.11114/bms.v1i2.820

Heyi, D. D., \& Mberengwa, I. (2012). Determinants of farmers' land management practices: The case of Tole District, south west Shewa zone, Oromia national regional state, Ethiopia. Journal of Sustainable Development in Africa, 14(1), 76-96.

Khapayi, M., \& Celliers, P. R. (2016). Factors limiting and preventing emerging farmers to progress to commercial agricultural farming in the King William's Town area of the Eastern Cape Province, South Africa. South African Journal of Agricultural Extension (SAJAE), 44(1). https://doi.org/10.17159/2413-3221/2016/v44n1a374

Kepe, T., \& Tessaro, D. (2014). Trading-off: Rural food security and land rights in South Africa. Land Use Policy, 36, 267-274. https://doi.org/10.1016/j.landusepol.2013.08.013

Křičková, A. (2015). Reconstruction and Development Programme as a Tool of Socioeconomic Transformation in South Africa. Modern Africa: Politics, History and Society, 3(1), 57-93.

MacLeod, N. D., McDonald, C. K., \& Van Oudtshoorn, F. P. (2008). Challenges for emerging livestock farmers in Limpopo province, South Africa. African Journal of Range and Forage Science, 25(2), 71-77. https://doi.org/10.2989/AJRFS.2008.25.2.5.484

Mafukata, M. A. (2015). Factors having the most significance on the choice and selection of marketing channels amongst communal cattle farmers in Vhembe District, Limpopo $\begin{array}{llll}\text { Province. Journal of Human } & \text { 77-87. }\end{array}$ https://doi.org/10.1080/09709274.2015.11906826

Meijer, S. S., Catacutan, D., Ajayi, O. C., Sileshi, G. W., \& Nieuwenhuis, M. (2015). The role of knowledge, attitudes and perceptions in the uptake of agricultural and agroforestry innovations among smallholder farmers in sub-Saharan Africa. International Journal of Agricultural Sustainability, 13(1), 40-54. https://doi.org/10.1080/14735903.2014.912493

Mpandeli, S., \& Maponya, P. (2014). Constraints and challenges facing the small scale farmers in Limpopo Province, South Africa. Journal of agricultural Science, 6(4), 135. https://doi.org/10.5539/jas.v6n4p135

Mukwevho, R., \& Anim, F. D. K. (2014). Factors affecting small scale farmers in accessing markets: a case study of cabbage producers in the Vhembe District, Limpopo Province of South Africa. Journal of Human Ecology, 48(2), 219-225. https://doi.org/10.1080/09709274.2014.11906791 
Mwadzingeni, L., Mugandani, R., \& Mafongoya, P. (2020). Localized institutional actors and smallholder irrigation scheme performance in Limpopo province of South Africa. Agriculture, 10(9), 418. https://doi.org/10.3390/agriculture10090418

Netshipale, A., Oosting, S. L., Raidimi, E. N., Mashiloane, M. L., \& de Boer, I. J. (2017). Land reform in South Africa: Beneficiary participation and impact on land use in the Waterberg District. NJAS-Wageningen Journal of Life Sciences, (83), 57-66. https://doi.org/10.1016/j.njas.2017.07.003

Nuthall, P. (2012). The intuitive world of farmers-the case of grazing management systems and experts. Agricultural Systems, 107, 65-73. https://doi.org/10.1016/j.agsy.2011.11.006

Quinn, C. H., Ziervogel, G., Taylor, A., Takama, T., \& Thomalla, F. (2011). Coping with multiple stresses in rural South Africa. Ecology and Society, 16(3). https://doi.org/10.5751/ES-04216-160302

Raleting, P. M., \& Obi, A. (2015). An analysis of institutional factors influencing vegetable production amongst small-scale farmers in six vegetable projects of the Nkonkobe Local $\begin{array}{lllll}\text { Municipality. Journal of Agricultural Science, } & 7(6),\end{array}$ https://doi.org/10.5539/jas.v7n6p184

Salami, A., Kamara, A. B., \& Brixiova, Z. (2017). Smallholder agriculture in East Africa: Trends, constraints and opportunities. Tunisia: African Development Bank Tunis.

Sobczyk, W. (2014). Sustainable development of rural areas. Problemy ekorozwoju-problems of sustainable development, 9(1), 119-126.

Sjauw-Koen-Fa, A. R., Blok, V., \& Omta, S. W. F. (2016). Critical Success Factors for Smallholder Inclusion in High Value-Adding Supply Chains by Food \& Agribusiness Multinational Enterprise. International Food and Agribusiness Management Review, 19(1030-2016-83100), 83-112.

Statistics South Africa (2019). Quarter on Quarter Report. Department of Statistic South Africa.

Statistics South Africa (2020). 2020 Mid-year population estimates. Department of Statistic South Africa

Sutherland, L. A., \& Burton, R. J. (2011). Good farmers, good neighbours? The role of cultural capital in social capital development in a Scottish farming community. Sociologia Ruralis, 51(3), 238-255. https://doi.org/10.1111/j.1467-9523.2011.00536.x

Tshuma, M. (2012). The land reform programme (LRP) as a poverty alleviation and national reconciliation tool: The South African story. African Journal of Agricultural Research, 7(13), 1970-1975.

Vermeulen, S. J., Aggarwal, P. K., Ainslie, A., Angelone, C., Campbell, B. M., Challinor, A. J., ... Wollenberg, E. (2012). Options for support to agriculture and food security under climate change. Environmental Science $\mathcal{E}$ Policy, 15(1), 136-144. https://doi.org/10.1016/j.envsci.2011.09.003

Vetter, S. (2013). Development and sustainable management of rangeland commons-aligning policy with the realities of South Africa's rural landscape. African journal of range $\mathcal{E}$ forage science, 30(1-2), 1-9. https://doi.org/10.2989/10220119.2012.750628 
Vukelić, N., \& Rodić, V. (2014). Farmers management Capacities As A Success Factor In Agriculture: A Review Economics of Agriculture, 61(297-2016-3600), 805-814.

White, B. (2012). Agriculture and the generation problem: rural youth, employment and the future of farming. IDS Bulletin, 43(6), 9-19. https://doi.org/10.1111/j.17595436.2012.00375.x

Yusoff, M. A., Man, N., \& Nawi , N. M. (2016). Exploring Critical Success Factors for Stakeholder Management in Small Ruminant Farming. Journal of Advanced Agricultural Technologies, 3(4), 239-246. https://doi.org/10.18178/joaat.3.4.239-246 